\title{
Women Watering Basil Plants: New Insights into a Spanish Moroccan Folktale
}

\author{
Mujeres que riegan plantas de albahaca: \\ Nuevas aportaciones sobre un cuento popular marroquí español
}

\author{
Adriano DUQue \\ (Villanova University) \\ adriano.duque@villanova.edu \\ ORCID ID: 0000-0002-8255-5231
}

\begin{abstract}
This paper examines the Spanish song «Princesita que riega la albahaca» and compares it with other Moroccan versions of the folk tale. Although loosely based on the encounter between King Solomon and Queen Sheba, the story incorporates a series of elements from different folk traditions, while insisting on the motif of the husband-seeking maiden. Drawing on the motifs of the garden or the mother, the essay examines how the protagonist of the story uses the metaphor of the Basil plant to articulate relations of exogamy and to question social assumptions regarding the role of women and their social constraints.
\end{abstract}

KEYWORDS: basil, exogamy, matrimony, PALABRAS-ClAVE: albahaca, exogamia, Morocco, arabic folklore
RESUMEN. El presente artículo examina la canción en español «Princesita que riega la albahaca» y la contrasta con otras versiones marroquíes del cuento. Aun basándose relativamente en el encuentro entre el rey Salomón y la reina de Saba, la historia incorpora una serie de elementos de diferentes tradiciones populares al tiempo que insiste en el motivo de la doncella que busca marido. A partir de los motivos del jardín o de la madre, el ensayo examina cómo el protagonista de la historia utiliza la metáfora de la planta de albahaca para articular relaciones de exogamia y para cuestionar los presupuestos sobre el papel de las mujeres y sus limitaciones en sociedad.

matrimonio, Marruecos, folklore árabe

Basil plants stand at the core of several Spanish and Moroccan folktales. In these stories, a woman waters a garden plant to attract the attention of her lover. The present articles studies certain aspects of these accounts, paying special attention to the literary motifs and the recurrent themes that culminate with an act of marriage and the bride's change in social status. This emphasizes the initiatory dimension of the tale. In other words, the marriage of the protagonists facilitates the passing from one social group to another through a process of identification and substitution of the father.

This article parts from the assumption that plant watering belongs to the category of the disorderly. Every time a woman is seen washing clothes of watering plants, she exposes herself to the gaze of a man and opens the door to sexual misconduct. Regarding the water motif, Pedro Piñero has observed how that the motif of water in the Spanish ballad tradition can be analyzed on two levels: as the symbolic representation of the legitimate union between a man and a woman or on the level of the sexual and illegitimate 
union between a man and a woman, who face social impediments to their marriage (Piñero, 2004).

In the Moroccan Histoire du Pélerin, the daughters of a King climb up to the terrace of their house to water a plant of basil and to look at a passing prince (Légey, 2010: 18). In reading these stories, an important motif emerges: that of the curious woman who ventures into the garden not only to perform her duties as a daughter but also to expose herself to any potential suitors. As the narrative unfolds, and just as garden space facilitate the encounter between two lovers, the plant of basil becomes the visible instrument uniting two people from very different social backgrounds. A version recorded by Abderrahman Yebbur-Oddi stresses the intimate bind that is formed between woman and plant:

Se cuenta que antiguamente el hijo de un sultán subía a la azotea de su serrallo y preguntaba a una bella doncella vecina suya, diciéndole: «ioh, bella enamorada de la albahaca!, dime, por Dios, ¿cuántas hojas tiene?» A lo que contestaba la doncella: «Tú señor, que eres sabio versao, dime, por Dios, ¿cuántas embarcaciones existen en el mar y cuántas estrellas pueblan el espacio?» (Yebbur, 1950: 57-58) ${ }^{1}$

The different motifs that build this Moroccan story can also be traced back in several Spanish versions of the folktale, which are characterized as «an impediment to marriage» (Goldberg, 2015: 145). But unlike the Moroccan versions of the story, the Spanish folktale introduces a number of episodes (the kissing salesman or a turnip penetration) that represent, albeit metaphorically, the social intercourse and transgression that takes place between a man and his newly found bride. In this story, a man of superior status must circumvent the social barriers that impede a morganatic marriage between the main characters.

According to the version recorded by Aurelio Espinosa in 1924, a mother asks her three daughters to water a pot of basil. A prince who asks how many leaves are there in the plant taunts the third sister. She counters him by asking how many stars there are in the sky. He then disguises as a peddler and exchanges a ribbon for a kiss. He then adds this to their daily duel. The prince becomes sick, she disguises as a doctor and makes her way into the royal palace. She introduces a turnip up the prince's rear end. Later on, as he is confronted by the maiden, the prince surrenders to her intelligence and recognizes her ability to overpass social boundaries. Finally, they decide to marry (Espinosa, 1924: $31-35)^{2}$.

The image of a woman watering a plant of basil conjures images of rogue women ready to expose themselves in order to get the attention of innocent bystanders. In every instance, the woman remains the product of the man's desire but she does so by creating

\footnotetext{
${ }^{1}$ The motif reappears in a Mexican bomba yucateca, a saucy couplet from Yucatán that is usually sung as a prelude to the zapateado. In this story, a woman is approached by a man who sees her for the second time in the day. Earlier that morning, he recalls, she was holding a hose and watering a palm tree (huano). The woman affects indifference and pretends she did not see him, distracted as she was by the scent of a x'kanlol, a small tree with clusters of yellow flowers: «Esta mañana te vi / con tu manguera en la mano/ regabas a (sic) tu jardín / bajo una mata de huano. / En cambio yo no te vi, / porque regaba mis flores, / distraida solo olí / al x'kanlol de mis amores» (Azcorra, 2007: 19).

2 The Spanish version coincides with the Dutch version in the first two elements: the riddle of the plant and the number of stars in the sky (Stith Thompson H705.3). Then follows a series of tricks and countertricks that involve the transformation of the main character into a fisherman, a kiss on the horse's leg, a hiding under the bed to prick the maiden with a needle, a threat of death and the substitution of the maiden by a sugar doll. See The Basil maiden (Goldberg, 2015: 145).
} 
her own world. The world that surrounds the maiden is clearly represented by the basil plant and becomes the expression of a symbolic landscape that is continuously transgressed. The typical association between plant watering and sex transforms a seemingly innocent act into a full-fledged sexual provocation. It is in fact through plant watering that the maiden can manipulate her identity and bring much sought changes in her own life.

\section{THE PLANT OF BASIL}

Basil is an aromatic plant that is usually cultivated in partial sun exposure. As it is customary in Mediterranean climates, basil plants are only watered in the late afternoon, once the heat has started to subside. When watered, the basil plant emits a strong scent. It is possibly for this reason that folktales present basil as a means of communication between men and women, or more specifically between a woman who is enclosed in the space of a garden and a suitor who does not belong to her family circle. By virtue of this scent, the seemingly innocent woman will get the attention of the passerby and facilitate an encounter that will lead to gradual mutual infatuation.

Moroccan folklore considers basil as a sedative against melancholy (Akhmisse, 1985: 131). Basil is also mentioned as a means to assure the wellness of marriage (Légey, 2009: 235). Françoise Légey describes a blessing ritual from Marrakech whereas a doll was made to protect the house. In lieu of their head, the doll was topped with a bouquet of basil. The doll was then placed above the main door of the house so that it could welcome any stranger coming in (Légey, 2009: 332). Gustave Jeannot describes the use of the plant of basil as a metaphor of the man's power in Berber wedding rituals and he explains how on the wedding night the groom was stripped of his basil plant and the dagger: «Un jeune homme prend alors la fiancée sur son dos et la porte à la chambre nuptiale, pendant que d'autres lui enlèvent son bouquet de basilic, son poignard» (Jeannot, 1907: 135) ${ }^{3}$.

Still within the tradition of Tetuán in North Morocco, the plant of basil appears in a series of short paremiological poems introducing other folktales. Although the poems vary in length and content, they suggest the existence of an archetype telling the encounter of two lovers who are in turn represented by two plants. This is at least the meaning of a version recorded by Malīkā al-Asāmī (Heller-Goldenberg, 1983: 33). In this version, the basil plant is opposed to the lily. This opposition suggests a gendered contract between basil and lily, which tend to be associated with female and male scents, respectively:

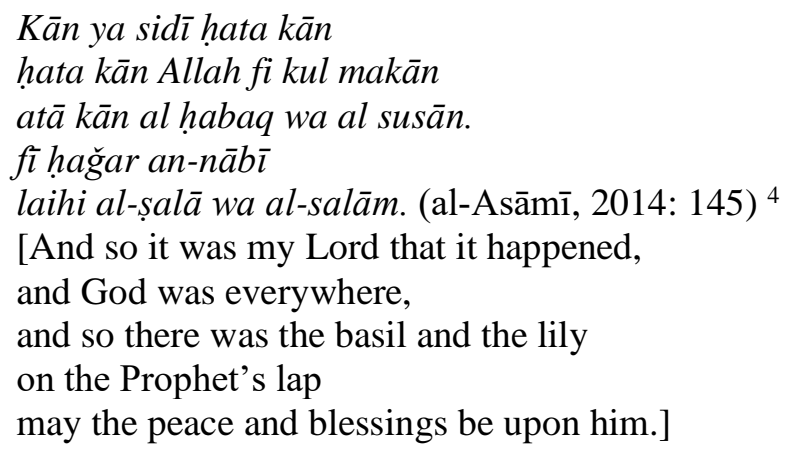

\footnotetext{
${ }^{3}$ The mehabqa is recognized as a flower motif in Berber carpets (Ricard, 1923: 127).

${ }^{4}$ Maloom records this invocation as a traditional formula that is used when receiving flower or perfume gifts: «Lorsque l'on sent un parfum agréable, l'usage est d'adresser une prière sur le Prophète: allāhumma șalli wa-sallim ‘alā muḥammad wa-'alā ‘ālih»» (Maloom, 2009: 113).
} 
In Spanish folklore, basil is treated as a remedy against depression, against warts, against common cold or to alleviate the pains of birth (Agustí, 1722: 77; Maíllo, 1983: 214). Basil is also prescribed as one of the elements necessary to cast an evil eye on someone (Molho, 1950: 299). Another Spanish tradition tells how young women would put a plant of basil on their windowsill to attract any potential lovers ${ }^{5}$.

The pungent smell of basil signals the overwhelming attraction that a man feels for the maiden and conjures images of women being harvested from their father's garden. This idea is consistent with other representations of female abduction like the Veneno de Moriana, where a woman must chide the advances of her father and seek viable alternatives to her reclusion in the familial garden (Wolf, 1844-1846: 25). The motif of basil as a sexual trope reappears in the romance de Bravonel, where a knight is said to admire carnations but will nevertheless faint every time he smells the plant of basil:

Las clavelinas le encienden,

la albahaca le desmaya,

que es de natura en amor

una esperanza muy alta. (Wolf, 1844: 1846: 154)

Like the plant of basil, the woman becomes a sensual commodity signaled by her own scent. This allows for a metonymic exchange between woman and plant. In this mixture of metonymy and metaphor, the folktale confronts the reader with a situation in which the physical reality of the character is supplanted by her own fictional representation. Along this process, the metaphor takes over the metonymy itself. This transformation is made clear in an epithalamic song of Extremadura, where the bride is said to be a plant of basil. The wealthy arrangement of the wedding feast suggests a rich celebration where the woman is exposed to the gaze of all men:

\author{
A coger los manteles \\ y los cubiertos de plata \\ que venimos a ver la novia \\ que es un ramo de albahaca. (García Matos, 1982: 281)
}

The identification between maiden and garden plants leads to several erotic double entendres where the basil plant becomes a metonymic representation of the female parts. These double meanings become poetic devices that engage the interest of the reader. On the other hand, the need for an irregular encounter calls out to a certain social disparity between the two lovers that often unveils the impropriety of the maiden who exposes herself to the gaze of her lover. This is made clear in a song from Guijo de Galisteo (Cáceres) where young women are said to refresh their private parts in the cold waters of the silver stream. This action replicates the erotic association between the plant and water. This explicit image conveys the existence of a remote place, an enclosure of delights, where social rules are broken and where women can be easily be glanced at while they hackle themselves:

\title{
En el pueblo de Portaje
}

\footnotetext{
${ }^{5}$ Cf. the proverb «Por santa Águeda si ya no lo hicieste, siembra tu alhábega» (Correas, 2003: 83). Saint Agueda was usually invoked by young women seeking a husband. See also the poem: «Toma este ramo de albahaca, / que lo corté para ti, / la mañana de San Marcos, / el veinticinco de abril» (Ruiz, 2008: 33).
} 
hay un arroyo de plata

a donde acuden las mozas

a lavarse la albahaca. (Domínguez Moreno, 2006: 8)

As this song evidences, female attraction can never exist in isolation and demands the presence of a viewer. The social consideration of the woman remains dependent on the recognition of the male prince. But getting the prince's attraction is not enough as he needs to be convinced and persuaded about the suitability of the woman. Even if the prince can enter her garden, the watering of the basil plant evidences the woman's failure who despite her impudence still depends on her lover to leave the family enclosure. Due to her own social upbringing, the woman is in fact barred from entering the world of the prince. In order to circumvent the social barriers that separate them, the woman will need to rewrite the social rules that guide the relation between a woman and her suitor. Riddle making becomes especially important, because it helps establish a certain balance between the prince and the woman and signal her as a suitable candidate for marriage.

\section{RIDDLE MAKING}

Riddle making initiates a situation that is only known to the riddle maker. In the riddling process, the norms of interrogation are reversed to the extent that the person asking the question already has an answer to it. It is not expected that any other person could solve the riddle. Consequently, the riddle allows the two characters to engage in a legal strife that will lead to a public act of humiliation. In this sense, the riddle is seen as an element of possible intimidation, a challenge to the ignorance of the recipient who is placed in a vulnerable position.

The shaming power of riddle becomes especially relevant in the story of princesita, as it mars the dynamics of cooperation between the maiden and the prince. It is through the riddle that the maiden will establish her superiority over her own sisters and it is also through the riddle that the prince will come to recognize her as a suitable candidate for marriage.

The relation between riddle and lovemaking is predicated on the clear difference that exists between the frame tale and the riddle (Goldberg, 2015: 79). While the frame tale allows for a presentation of the story, the riddle opens itself to a series of unexpected situations that will lead to an amorous encounter. The independent life of the riddle is best described through a series of tales where the narrative framework acquires a secondary role and where the riddle examines the personal worth of the maiden. This examination allows in turn for the construction of a series of motifs, like riddle making or character transformation that can already be found in the Semitic tradition of Queen Sheba.

The comparison between the story of Queen Sheba and the story of princesita rests on a number of folkloric motifs that will ultimately lead to a scene of riddle making. This riddle scene will in turn allow to establish the tenets of Sheba's character and establish a model of aspirations that she will need to fulfill, before marrying King

\footnotetext{
${ }^{6}$ Maximiliano Salinas Campos records another song: «Vengan a los claveles / que aquí tengo las albahacas / para las niñas retacas/ y otra cosa no se huele [...] esta noche principió / el contento y la alegría» (Salas, 2000: 247).
} 
Solomon. Like in the story of princesita, the motif of riddle making will conclude with an act of marriage. This will symbolically lead to an act of religion conversion ${ }^{7}$.

According to Middle Eastern tradition, Queen Sheba was thought to have a goat's hoof as a foot (Kluger, 1974: 114). In order to dispel this rumor, King Solomon ordered to build a palace with glass floors. His intent was to make a resemblance of water in the reception halls. As she entered the palace, Queen Sheba lifted her skirt to walk over the flood. In doing so, she exposed her feet. This is how it came to be known that she had normal feet:

The court demons, fearing that he may marry Balqis, told him that she had the hoof of an ass and hairy legs. The king had glass installed in the front of his throne so that the queen mistaking it for water, raised her skirt, revealing that she did not have hairy legs. (Jackson-Laufer, 1999: 46)

The demonic attributes of Queen Sheba are suggestive of some likely Mesopotamian representations of Ereshkigal or Ishtar with animal feet found in the Burney Relief, yet is was quickly assimilated into Arabian folklore ${ }^{8}$. On the other hand, the idea of a maiden treading on glass floors remains especially close to the European story of Cinderella (and her famous glass slipper (ATU 510A). The explanations are numerous and invariably point out to the existence of a trial by which the maiden distances herself from other female contenders. The earliest version of the story is recorded in Strabo's Geography, where it is told that a maiden, Rhodopis, has her shoe stolen by an eagle, which took it to the King. The King then searched for the owner of the slipper and married her (Strabo 17.1.33).

For William St. Clair Tisdall, the presence of the glass slipper rests on a confusion between the terms «verre» and «vair», which is a more natural material for a shoe (St. Clair Tisdall, 1911: 80). For Alan Dundes on the other hand, the glass shoe functions as a metaphor of virginity, in considering that «glass is fragile and once broken it cannot be repaired» (Dundes, 1989: 139).

The importance of the shoe lies in its value as a test to measure the qualities of the maiden. A woman whose foot fits the prince's shoe will signal herself as the chosen bride and allow for a period of recognition that will ultimately lead to the union between spouses. Therefore, the shoe provides a point of stability in the narrative that will lend itself to a variety of encounters. It also offers the female character an opportunity to demonstrate their skills and capabilities. This, in turn, allows them to become vehicles through which the tale communicates a particular worldview.

While the motif of the glass slipper is not present in all versions of the Cinderella story ${ }^{9}$, it nevertheless points out to the need of qualifying the maiden and making her embody certain societal ideals. As in the stories of princesita and the Queen of Sheba, the riddles help establish the tenets of the woman's abidance to those same rules. Once the woman convincingly answers the riddles, she engages with the man on equal terms and offers a safety valve through which social stratification can be maintained. At the same time, the characterization between the woman and her suitor is heavily dependent on the

\footnotetext{
${ }^{7}$ Jacob Lassner records in this regard the opinion of an unnamed scholar for whom all the folktales go back to the archetype of the story of Cinderella (Lassner, 1993: 124).

${ }^{8}$ Cf. British Museum, 2003, 0718.1.

9 According to a study conducted in 1892 , only six of 245 versions of Cinderella mention the glass slipper (Dundes, 1989: 47).
} 
riddle that will add animation to the tale. It is largely through the riddle that the audience will come to understand the terms of their relationship.

The maiden's change of status is best reflected through Queen Sheba's conversion to Judaism and her willingness to relinquish her own faith. It is only when she understands the tenets of Judaism that she can convert to Judaism and marry King Solomon ${ }^{10}$.

The riddle episode occurs in the space of a garden that functions as a place of reunion, a place where men and women meet, distanced from the constrains of daily life in society. According to an Arabian tale, when Queen Sheba decided to meet King Solomon, she did so in his own garden. As they meandered through it, she pronounced three riddles. The first riddle pertained to the female's birth cycle. The second riddle referred to the family unit. The third riddle indicated the differences between males and females. The same tradition tells how after hearing all of Solomon's wisdom, Queen Sheba praised the God of King Solomon and expressed her desire to join the people of Israel (Kadari, 2009) ${ }^{11}$. The suggestion that the riddles may summarize the tenets of Jewish faith (Coltri, 2011) highlights the ability of these same riddles to become depositaries of social norm and constitute a vehicle for rightful conversion. Rather than expressing the intelligence of the person being interrogated, they express the interrogator's willingness to accept the new status quo ${ }^{12}$.

Queen Sheba's conversion signals a change in status that results from the newly established relationship. Much like the princesita's unequal marriage, Queen Sheba's alleged conversion to Judaism signals a process by which one person moves from one religious group to another. Like in the story of princesita, riddle making initiates a process of interpellation where the maiden and the prince challenge all the social practices they are said to embody (Bourdieu, 1977: 15). In that case, riddle making allows also for a structured social-symbolic exchange between the two characters and allows them to adapt to the new social structures they generate, enabling the riddle maker to demonstrate a «certain control over the focal point of the environment or the crucial transactions» (Goldberg, 2015: 164), opening the door to a social exchange that would otherwise remain impossible. This exchange is exemplified in the multiple personalities that the characters will adopt in order to physically approach each other.

\section{GENDER REVERSAL}

Role exchange in folklore conveys a rupture of the social structures that regulate normal social behavior. In every version of the princesita story, the role of the prince is

${ }^{10}$ In the Qu'ranic version, Balqis is a repugnant pagan who worshiped the sun instead of Allah (Quran 27: 23). Later Islamic writers told the story of their marriage and how they produced a male heir, Menelik, from whom the Ethopians were descendants (Coulter-Harris, 2013: 122). Mustansir Mir discusses Queen Sheba's hasty conversion to Judaism and suggests that the water scene presents a moment of illumination initiated long before her visit to King Solomon (Mir, 2011).

${ }^{11}$ The riddles of Queen of Sheba are nothing but a repetition of the words of seduction, which the first Lilith spoke to Adam (Scholem, 2017: 18).

12 There are numerous traditions establishing the association between Solomon and the riddle. For example, in the Book of Judges, we read that Samson engaged in riddles with his opponents (Judges 14:12, 18.) It is not inconceivable that the Queen of Sheba also had a passion for riddles, since she «came to prove him with hard questions» (1 Kings 10:1). Solomon is said to have collected over 3,000 proverbs or folk sayings filled with practical advice from around the Near Eastern world. The book of Proverbs in the Bible are thought to have originated from Solomon, as are the Song of Solomon and even the book of Ecclesiastes is attributed to some as Solomon's wisdom in his declining years (Delitzsch, 1874: 23). Menéndez Pelayo relates the story of Solomon and Queen Sheba to a series of basque traditions which would have inspired Alejandro Herculano to compose his story La dama del pie de cabra (Menéndez Pelayo, 1906: 55). 
split between the suitor and the rogue and is subject to a categorization that will turn the prince into the maiden's unknowing subordinate. This exchange is in turn regulated by a series of conventions that are exclusive to folktales. As Ignacio Ceballos points out, when a woman takes on a masculine role, she inaugurates a period of social instability that needs to be corrected. When a man takes on a female role, he does so to solve a pressing problem (Ceballos, 2012: 503).

Folkloric tradition relies on an equal distribution of roles, which tends to identify the daily chores with certain gender specific tasks. This is clearly stated in the tradition of the Ballad of don Bueso, where memory functions as a repository of an ideal social order. The ballad in question tells the story of a man who goes to the land of the Moors to snatch an «amiga». He then finds a woman washing her clothes by the river. When he mounts her on his horse and returns to the homeland, the maiden recognizes the olive grows planted by her father and remembers how her mother used to weave silk while her brother fought bulls. Precisely then, the maiden realizes that they are brother and sister and they celebrate their encounter:

cuando el rey mi padre plantó aquí esta oliva,

la reina mi madre las sedas torcía,

mi hermano don Hueso los toros corría.

(Cossío, 1933-1934, 343, vv. 13-17)

The equal distribution of tasks conveys a stark contrast with ideal past and establishes an aspiration to correct the degradation of the present moment. In this setting, the characters acquire new temporary identities that allow them to cope with the existing situation. Social change acquires special relevance in the story of the princesita, when the prince decides to dress as a lace maker. Having shown the princesita a piece of lace, he refuses to give it away unless she kisses him. By disguising himself as a peddler, the prince puts himself on equal footing with the maiden and extracts a kiss from her. Along this process, the prince makes the maiden into accomplice in her own seduction.

Lace trading is essentially a female task. This can be inferred from stories like the Tragicomedia de Celestina $(3,1,128)$, where it is the old prostitute that uses her trade to go from house to house and persuade Celestina to surrender to the lust of Calisto (Macpherson, 1992: 185). Nevertheless, the motif of the lace salesperson is a common trope in Spanish folklore and appears in a number of stories where a man who sales lace loiters around a woman's house. This is at least the meaning of a song in a tradition of Badajoz, where a woman longs for a very graceful encajero.

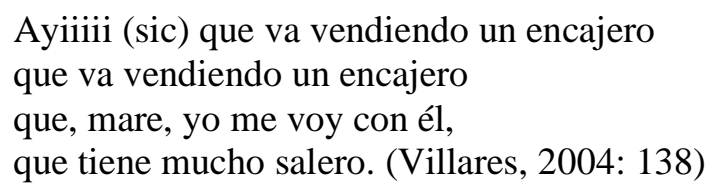

While he is away, his wife cheats on him with another man. The encajero's ability to enter different household is seen as an opportunity for deviant behavior and presents him both as perpetrator and as victim of sexual misconduct.

In a second song, the encajero's frequent absences put him in a vulnerable position. When he returns, the wife manages to get her lover out of the house and tells her own husband how lucky he is. If he had married another woman, he would be cheated on 
more occasions that a cattle ranch has horns. The double entendre is clear. Even though the woman is being unfaithful, she is still not as unfaithful as she could be:

Que si tú con otra te hubierah (sic) casado

Yevaríah máh cuerno que yeva un Ganado. (Gil, 1931: 23-24)

The vulnerability of the maiden is invariably represented as an act of social duplicity and social reversal by which the suitor adopts the personality of someone belonging to a lower social scale. The social transgression that results from this impersonation demands a parallel development on the part of the woman and will help her cast sexual reversal as a means of social impersonation. Against the peril of the encajero who uses his trade to enter the woman's space, the story of princesita opposes the image of a maiden, who disguises herself as a doctor, and who uses her disguise to introduce herself into the private quarters of the prince.

Like in the encajero stories, the status of the princess is undermined by the competitive nature of the male. In disguising herself as a doctor, the maiden relinquishes her own normal representation and adopts the personality of a person who is superior to her peer. This impersonation calls for a physical interaction whereas the different characters express their own special understanding of social structures. The newly balanced relation between a prince turned peddler and a bride turned male doctor consolidates this.

On a secondary level, the transformation of the maiden involvers a physical displacement whereby the maiden enters the private space of the prince. The maiden's march into the prince's palace stands as a clear reflection of the social suppression that is taking place. It also allows for a stepping out of ordinary life into a temporary sphere of non-serious activity where she humorously penetrates the prince with a turnip. The erotic language of penetration enacts a pursuit and violation of the laws that regulate social status and serve to satisfy the reader's fascination with the interiority of the prince's world and the maiden's desire to take possession of him.

The suppression of traditional roles in the princesita story provides a mechanism for social bonding between the maiden and the prince. It also allows the characters to share a social space where the union with the prince becomes a virtual appropriation of his physical body. The turnip penetration becomes crucial, inasmuch as it allows the maiden to initiate an act of public shame that will underscore the dependence between her and the prince. The turnip allows the maiden to bring to the forefront and expose the social principles that will regulate the prince's behavior, to her own advantage.

The use of turnips has a long tradition in European folklore and can be found in stories like Die drei Federn, where a toad is placed inside a turnip, later to become a princess inside her carriage (KHM 63).

The different elements of Die drei Federn point out to a constellation of motifs that are usually intertwined. The motif of the pumpkin turned carriage has a very plausible explanation in a series of Numskull stories where a pumpkin is said to be an ass egg (Stith Thompson J 1771.1 1319). In La ragazza serpe the female protagonist pulls up a turnip, releasing five toads, four of which grant her beauty, the last one cursing her. If the sunlight falls on her, she shall become serpent (Cox, 1967: 96). In The Marvelous oax, the stepmother spills turnip see and orders Cinderella to pick it up (Cox, 1967: 363) ${ }^{13}$.

${ }^{13}$ Cf. Pliny: «terram non morose eligit, paene ubi nihil aliud seri possit. nebulis et pruinis ac frigore ultro aluntur, amplitudine mirabili; vidi XL libras excedentia» (Historia Naturalis 18, 128). 
Finally, Franz Xavier von Schönwerth records a story where a prince finds a big turnip growing in the fields. He then sticks a branch with a red flower into it and falls asleep. When he awakes the next morning, the turnip had turned into a gigantic bowl. Inside the bowl he could distinguish the figure of a beautiful maiden (Schönwerth, 2015: 9) ${ }^{14}$.

In every folktale, the turnip articulates different levels of physical possession that can in turn clarify different levels of social worth. The person who owns the turnip becomes the center of attention and the purveyor of joy. This is the case of several Spanish traditional folktales and songs, where the turnip is made to signify the price of manhood. In these stories, the turnip is seen as a commodity that can increase the wealth of the farmer who hopes of an advantageous sale. Consequently, the turnip can be transferred from one person to another, leading to a humorous double entendre which further underscores the value of the social transaction that is taking place. By transforming the turnip into a sexual toy, the protagonists of princesita engage the attention of the reader who is now able to partake in the development of the story. The social connotations attributed to the turnip function as a prolepsis, as an anticipation of the dénouement of the story ${ }^{15}$.

By considering these aspects, the reader who reads the story of a man being penetrated by a turnip is reminded of the vulgar connotations of the image of a maiden penetrating her lover with a turnip ${ }^{16}$. This association is made explicit in songs like $M i$ abuelo tenía un güerto where an old man falls in hard times, hopes for a good economic gain, and finally manages to sell his turnips to a convent of nuns:

Yo tenía una huerta toda sembrada de granos; cuando vino la cosecha todas se volvieron nabos.

Me compré un borriquito para carretar los nabos.

En el medio del camino me salieron los gitanos,

me robaron el borrico, los nabos me los dejaron.

Fui al convento mayor por ver si compraban nabos;

salió la madre abadesa. A todas nos gusta el nabo. (Catalán, 1998: 349)

The economic transaction that takes place frames the sexual encounter as a symbolic change in status. The man that parades his turnip(s) is able to play on the meaning of his transaction to convey a successful economic exchange that will ultimately lead to social improvement. The grain grown in the orchard allows the man to buy a donkey, which in turn he uses to sell the turnips that the nuns will buy ${ }^{17}$.

\footnotetext{
${ }^{14}$ Within the Spanish tradition, the German Rapulzen is often known as «nabiza». Cf. also story Die Rübe, where a man grows an enormous turnip which he offers to the king and is later rewarded, attracting the jealousy of his brother (KHM 146; Ziolkowski, 2010: 178).

15 Anal penetration was in fact a grave offense and as such it was codified in the fuero de Valencia, which considered great fault in penetrating someone with a stick: «Finalrnente, aquel que meta a otro, fuera de su casa, palo por el culo, comete una gravisima injuria» (Cod. Val., 2, 2, 28; Madero 1992: 77).

${ }^{16}$ In the Tragicomedia de don Duardos by Gil Vicente, the characters reunite in Flérida's orchard. Signaling his preparedness, Juan declares «Pues tengo el nabo regado / y el rosal apañado, / ¿no merezço la comida?» (538-541).

${ }^{17}$ The turnip song has a long tradition in Spanish folklore, as part of a series of «canciones burlescas» where an old man is said to have a tree on which different and unexpected plants are seen. Nieves Vázquez Recio records a variant where the turnip is substituted by a lily, nevertheless maintaining the innuendos of a sexual economic transaction: «Mi abuelo tenía un huerto todo sembrado de nardos» (Vázquez, 2000: 332). The turnip story is especially close representation a two nuns who collect fruits from a penis tree. This image belongs to a manuscript of the Nom de la Rose from the $14^{\text {th }}$ century (Man. FR 2526).
} 
In similar fashion, José Manuel Pedrosa has called attention to La cena de los nabos, a Sephardim wedding song from the North of Morocco. Speaking on the tradition of the turnips, Pedrosa signals the numerous beliefs in the aphrodisiac power of turnips (391), and their metaphoric significance (Pedrosa, 2011: 394). Most interestingly, he records a song from Galicia, where a woman rejects the turnips from a man's orchard in a display of humorous refusal, afraid as she is of the man's gird:

Non chas quero, non chas quero,

nabizas do teu nabal(e);

non chas quero, non chas quero

que me poden facer mal(e). (Pedrosa, 2011: 398)

The residual plot that follows the turnip penetration is generally positive. Taken as a sign of social transgression, the handling of the turnip allows the maiden to act outside normal social conventions and avoid the usual embarrassment that such action could incur. An examination of the prince's reaction suggest that the positive outcome depends on the importance of the norm that is being broken and the reward that the maiden will receive once she has effectively broken the social norm.

The difference between Queen Sheba and princesita lies in their symbolic capital. While King Solomon keeps Queen Sheba within Judaic religion, denying her the ability to possess or access any kind of social capital, the prince in the princesita story, on the other hand, allows the maiden to remove herself from her role as a mere object of desire. But it is not a full removal. The maiden is quick to realize that her worth is dependent on her ability to adopt different social roles that fall outside her traditional gender assignment. More than her strength of character, the worth of the maiden resides in her ability to persuade the prince to seduce her, presenting herself as a grateful victim, when the fact is that she is a full-fledged instigator. The penetration into his chambers remains a startling metaphor for the violence that the woman experienced in her own garden. In this setting, the body of the prince represents the differences between the social entourage of the maiden and his own social group. It synthesizes the value of the prince's body as a prize that the maiden deservedly earns. The body of the prince becomes a source of distinction and a vehicle for social mobility.

In contrast with the vision that considers the relationship between the two characters from a mere economical point of view, the prince is neither presented as a pauper or a rich man, as a man or a woman. Just as in the case of the maiden, the prince is emancipated from his role as a social commodity and can escape from the violence associated with penetrating the woman's garden or his own bodily penetration. The maiden congruently escapes the weakness and feminity associated with her own sisters an can now safely navigate the streets of a town and a castle that would have normally been barred to her.

\section{UNDERSTANDING THE MAIDEN'S MOTHER}

In a previous essay on the Romance de don Bueso, I argued how the figure of the mother embodies the principle of legality in the absence of the father (Duque, 2011). Just as the father represents a coercive force intended to prohibit his daughter's wedding with a stranger, his removal at the beginning of the princesita story creates an initial imbalance that could be rectified by the introduction of a new male. In this sense, the father does not overshadow the suitor. Conversely, the mother functions as an agent for justice that stages the abduction of her own daughter. This lack of agency introduces a sense of uncertainty 
laying part of the guilt for any future abuse of the victim on the victim herself (Ashliman, 2005: 365).

The matrilineal impersonation of justice presents a problem because in conjures images of power-abuse and traditional hostility between the protagonist and her stepmother. This conflictive relation is best portrayed in the Italian story of Ermelina. In this tale, a woman sends her stepdaughter to water a basil plant that is sitting on a perilous ledge, in the hope that she will slip and die (Sherman, 2009: 173). Likewise, in one Slavic variant of the Cinderella story, the protagonist is forced out into the winter to complete an impossible task by her stepmother and stepsister, hoping that she will freeze to death (Sherman, 2009: 107).

The traditional antagonism between the unassuming girl and her evil stepmother evokes other representations of the story where the mother functions as a legal agent whose actions replace the vacuum of power produced by the absence of the father. In these stories, the mother functions and as mediator between the protagonist and a patriarchal power. Seeking a replacement, the maiden's only hope will be to find a suitable partner that can assume legal custody of her own world ${ }^{18}$.

The maiden that ventures into the garden to water the plant of basil does so at her own risk, and will therefore have to resist the advances of the handsome man. The maiden's obligation to follow the mother's rules fringes on involuntary homicide. Yet unlike the mother who represents the dominant value system, the maiden uses her own body to mediate the difference with the outside world. Against the constraints of the mother's garden, the maiden presents the mobility of a pot of basil that can be easily transported and moved around.

The mobility of the maiden's garden becomes a reminder of the maiden's ability to manipulate the space of her enclosure and to reach individuals from different social extraction. Whether the mother asks her to go out in the garden and water the plant of basil or whether she does it on her own accord, the maiden convincingly presents herself both as a victim and as instigator of her own abduction, something she uses to effectively to choose her own husband.

Considered both as an element of danger and hope, the plant of basil emerges as a trope of the woman's integrity and the price that a man will receive when and if he enters the garden. Just as the elder mother is supposed to safeguard the garden, the folktale explores how the loss of the father fractures and displaces the daughter's developing self. Having to fill the void left by the father, the maiden uses her own sexuality to obtain a suitable replacement and to seek social and public validation of her own self. Furthermore, in the case of the maiden, the daughter's quest becomes a route to recover the father's memory and to recover, albeit in a different scale, the initial bliss interrupted by the absence of the father.

The mother provides an important axis on which to consider the physical placement of characters in this narrative, highlighting the importance of her role in articulating relations of exogamy (Ceballos, 2009: 21). In her effort to escape the constraints of her own familial relations, the maiden uses the metaphoric space of the Basil plant to mediate the distance that separates her from the member of the social elite. The social differences that exist between the maiden and the prince become a reminder of the impossibility of their union and opens the door to a vetting process whereby the

\footnotetext{
${ }^{18}$ See for example, Teófilo's story in Los Milagros de Berceo. In this story, a priest from Sicily made a pact with the devil and then recanted. The Virgin the offered to recover the document that he had signed, giving his soul to the devil (Berceo, Milagros, vv. 47-74).
} 
maiden will prove to be an adequate candidate for marriage. The consequent penetration into the lover's garden or the impersonation of a doctor at the prince's palace become tropes of social intercourse and transgression where the humorous undertone gives way to a more problematic criticism of the social structures to which they eventually will abide.

\section{BIBLIOGRAFÍA}

AGUSTÍ, Miguel (1722): Libro de los secretos de agricultura, casa de campo y pastoral, Barcelona, Juan Piferrer.

AKHMise, Mustapha (1985): Médecine, magie, et sorcellerie au Maroc: ou, L'art traditionnel de guérir, Casablanca, Morocco, Benchar.

Amos, Ben (2011): Folktales of the Jews, Philadelphia, The Jewish Publication Society.

AL-ASAMī, Malīkā (2014): Mawsū'at al-thaqāfah al-sha 'bīyah wa-al-mìthūlūjiyā alMaghribīyah wa-hikāyāt nisā' Marrākush, al-Ribāṭ: Jāmi'at Muhammad alKhāmis, Kullīyat al-Ādāb wa-al-'Ulūm al-Insānīyah bi-al-Ribāṭ.

ASHLIMAN, D. L. (2015): «Step Relatives», in Jane GARRY and Hasan EL-SHAMY (eds.), Archetypes and Motifs in Folklore and Literature, Abingdon, Oxon and New York, Routledge, pp. 362-370.

AugsPaCH, Elizabeth (2004): The Garden as Woman's Space in Twelfth-and Thirteenth Century Literature, Lewinston, Edmin Mellen Press.

AZCorra Alejos, Jesús (2007): Bombas yucatecas, Mérida, Maldonado Editores del Mayab.

BAROJA, Carmen (1937): El encaje en España, Barcelona, Labor.

BELDEN, M. H. (1918): «Boccaccio, Hans Sachs, and The Bramble Briar», Publications of the Modern Language Association of America 23, 3, pp. 327-95.

DOI: https://doi.org/10.2307/456930

BERCEO, Gonzalo de (1997): Milagros, ed. Fernando Baños, Barcelona, Editorial Crítica.

BourdiEU, Pierre (1977): Outline of the Theory of Practice, trans. Richard Nice, Cambridge, Cambridge University Press.

DOI: https://doi.org/10.1017/CBO9780511812507

Catalán, D., J. A. Cid, B. Mariscal, S. Petersen, F. Salazar And A. Valenciano (1998): Romanceiro Xeral de Galicia, vol. 1, Madrid, Santiago de Compostela, Centro de Investigacións Lingüísticas e Literarias Ramón Piñeiro, Fundación Ramón Menéndez Pidal.

CEBAllos Viro, Ignacio (2012): «Las formas del trabajo femenino y su representación en el romance», Revista de Dialectología y tradiciones populares, 67, pp. 499514. DOI: https://doi.org/10.3989/rdtp.2012.19

COLTRI, Marzia (2011): «The Challenge of the Queen of Sheba: The Hidden Matriarchy in the Ancient East», Center for Studies on New Religions, 2011 (Viewed on September 20, 2016) <https://www.cesnur.org/2011/dan-coltri.pdf>

Correas Martínez, Miguel and José Enrique Gargallo GIL (2003); Calendario romance de refranes, Barcelona, Universidad de Barcelona.

Cossío, José María de y Tomás Maza Solano (1933-1934): Romancero popular de la Montaña: Colección de Romances tradicionales, Santander, Sociedad Menédez Pelayo. 
COUlter HARRIS, Deborah (2013): The Queen of Sheba: Legend, Literature and Lore, Jefferson, NC, McFarland.

Cox, Marian Roalfe (1967): Cinderella: Three Hundred and Forty-five Variants of Cinderella, Catskin and Cap O; Rushes, Nendeln, Kraus Reprint Ltd.

DELITZSCH, Franz (1874): Biblical Commentary on the Proverbs of Solomon, Edinburgh, T. \& T. Clark.

DOMÍNGUEZ MoRENO, José María (2006): «El retrato erótico femenino en el cancionero extremeño 1: Son tus muslos dos columnas», Revista de Folklore Extremeño, 307, pp. 3-16.

DUNDES, Alan (1980): Interpreting Folklore, Bloomington, Indiana University Press,

Dundes, Alan (1989): Folklore Matters, New York, Columbia University Press.

DuQuE, Adriano (2011): «Sex and the Border Byzantine Epics and the Spanish Frontier Ballad», Medieval History Journal, 14, pp. 213-228.

DOI: https://doi.org/10.1177/097194581101400204

DuRÁn, Agustín (1864): Romancero general ó Colección de romances Castellanos anteriores, vol. 2, Madrid, Rivadeneyra.

EliAS, Jamal (2009): «Prophecy, Power and Propriety: The Encounter of Solomon and the Queen of Sheba», Journal of Qur'anic Studies, 11, 1 pp. 57-74.

DOI: https://doi.org/10.3366/E1465359109000588

ESPINOSA, Aurelio (1924): Cuentos populares españoles, Stanford, Stanford University Press.

FRIEDRICH, Helen (1999): Oiseuse: an introduction to a homoerotic reading of Guillaume de Lorris's Roman de la rose, PhD Dissertation, University of North Carolina at Chapel Hill.

García MAtos, Manuel (1982): Cancionero popular de la provincial de Cáceres, Madrid, Centro Superior de Investigaciones Científicas.

GIL, Bonifacio (1931): Cancionero popular de Extremadura, Badajoz, E. Castells.

GOLDBERG, Christine (2015): Turandot's Sisters (RLE Folklore), A Study of the Folktale AT 851, Abingdon, Oxon, New York, Routledge. DOI: https://doi.org/10.4324/9781315730608

GRIMM, Jacob \& Wilhelm (1812): Kinder und Hausmärchen, Berlin, Realschulbuchhandlung.

HELLER-GOLDENBERG, Lucette (1989): «La culture populaire», Cahiers de la Méditerranée, 38, 1 pp. 23-43. DOI: https://doi.org/10.3406/camed.1989.1768

IBN Al HAJ AL-SUlAmI, JAFAR (2013): al-Astura wa al Maghreb al Aqsa, Tetuan, Asmir. JACKSON-LAUFER, Guida Myrl (1999): Women Rulers Throughout the Ages: An Illustrated Guide, Santa Barbara, ABC-CLIO.

JEANNOT, Gustave (1907): Étude sociale, politique et économique sur le Maroc, Dijon, Jacquot et Floret.

KADARI, Tamar (2009): «Queen of Sheba: Midrash and Aggadah», Jewish Women: A Comprehensive Historical Encyclopedia, 20 March 2009, Jewish Women's Archive, (Viewed on May 16, 2019) <https://jwa.org/encyclopedia/article/queenof-sheba-midrash-and-aggadah>.

KAPLANOGLOU, MARIANTHI (2016), «Spinning and Cannibalism in the Greek' Cinderella': Symbolic Analogies in Folktale and Myth», Folklore 127, 1 (Viewed on May 16, 2019), DOI: 10.1080/0015587X.2015.1093821

KLUGER, Rikvah Schärf (1974): Psyche and Bible: three Old Testament themes, Zurich, Spring Publications. 
LASSNER, Jacob (1993): Demonizing the Queen of Sheba: Boundaries of Gender and Culture in Postbiblical Judaism and Medieval Islam, Chicago, Chicago University Press.

LÉGEY, Françoise (2010): Contes et légendes populaires du Maroc, Casablanca, Morocco, Éditions du Sirocco.

LÉGEY, Françoise (2009): Essai de folklore marocain, Casablanca, Morocco, Éditions du Sirocco.

MACPHERSON, Ian (1992): «Celestina labrandera», Revista de literatura medieval, 4, pp. 177-186.

MADERO, Marta (1992): Manos violentas, palabras vedada. La injuria en Castilla y León (siglos XIII-XV), Madrid, Taurus.

MAíllo Salgado, Felipe (1983): Los arabismos del castellano en la Baja Edad Media, Salamanca, Ediciones Universidad.

MaloOM, Hanan, Julien Dufour, François Dumas (2009): «Expression de la politesse et de la civilité dans la société sanaanie», EDNA, 13, pp. 121-152.

MENÉndez PElayo, Marcelino (1906): Antología de poetas líricos castellanos: Tratado de los romances viejos, vol. 2, Madrid, Librería de Perlado.

MIR, Mustansir (2011): «The Queen of Sheba's Conversion in Q. 27: 44. A Problem Examined», Journal of Qu'ranic Studies, 9, 2, pp. 43-56.

DOI: https://doi.org/10.3366/E1465359108000053

Molho, Michael (1950): Usos y costumbres de los sefardies de Salónica, MadridCentro Superior de Investigaciones Científicas.

NEWMAN, Peggy (1977): «Mia madre velida: a figura da nai nas cantigas de amigo e nas jarcjas», Grial 55, pp. 64-70.

PASTERNACK, Nora (2005): Territorio de escrituras: narrative mexicana del fin del miledio, México, Casa Juan Pablos.

PedrosA, José Manuel (2011): «El epitalamio sefardí de La cena de nabos: metáfora y erotismo», in Elena Romero and Aitor García Moreno (eds.), Estudios sefardies dedicados a la memoria de Iacob M. Hassán (z"l), Madrid, Centro Superior de Investigaciones Científicas, pp. 387-417.

PIÑERO, Pedro (2004): «Lavar pañuelo lavar camisa. Formas y Símbolos Antiguos en Canciones Modernas, in Manuel Alvar, Pedro Piñero and Antonio José Pérez Castellano (eds.), De la Cancion de Amor Medieval a las Soleares: Actas del Congreso Internacional, Sevilla, Universidad de Sevilla, pp. 481- 497

RICARD, Prosper (1923): «Tapis de Rabat», Hésperis, 3, pp. 125-131.

RoJAS, Fernando de (1991): Comedia o tragicomedia de Calisto y Melibea, ed. Peter Russell, Madrid, Castalia.

RuIz, María Jesús (2008): Al vaivén del columpio: fiesta, coplas y ceremonial, Cádiz, Universidad de Cádiz.

SALAS CAMPOS, Maximiliano (2000): En el cielo están trillando: para una historia de las creencias populares en Chile e Iberoamérica, Santiago, Universidad de Santiago.

SCHOLEM, G. (2007): «Lilith», in Michael Berenbaum and Fred Skolnik (eds.), Encyclopaedia Judaica, vol. 13, Detroit, Macmillan Reference USA, p. 18.

SHERMAN, Howard (2009): World Folklore for Storytellers: Tales of Wonder, Wisdom, Fools, and Heroes, Abingdon, Oxon and New York, Routledge.

SCHÖNWERTH, Franz Xavier von (2015): The Turnip princess, trans. Maria Tatar, ed. Erika Eichenseer, New York, Penguin Classics, 2015. 
St. Clair Tisdall, William (1911): The Original Sources of the Qur'ân, New York, Society for Promoting Christian Knowledge.

STRABO (2002-2011): Geographie, ed. G. Aujac, Paris, Les Belles Lettres.

THOMPSON, Stith (1946): Motif-Index of Folk Literature: A Classification of Narrative Elements in Folktales, Ballads, Myths, Fables, Medieval Romances, Exempla, Fabliaux, Jest-Books, and Local Legends, 6 vols., Bloomington \& London, Indiana University Press.

VÁZQUEZ RECIO, Nieves (2000): Una «yerva enconada»: sobre el concepto de motivo en el romancero tradicional, Cádiz, Servicio de Publicaciones de la Universidad de Cádiz, Fundación Machado.

Vicente, Gil (1971): Tragicomedia de don Duardo, in Teatro anterior a Lope de Vega, Madrid, Edicones Alcalá, 1971, pp. 123-198.

VILLARES GIL, José Luis (2004): Los gitanos de Badajoz: romances, vida, costumbres, flamenco, Badajoz, Diputación de Badajoz.

Wolf, Ferdinand Josef (1844-1846): Romancero castellano, o Colección de antiguos romances populares de los españoles, Leipzig, F. A. Brockhaus.

YeBBUR ODDI, Abderrahman (1950): Antiguos usos y costumbres de Tetuán, Tetuán, Editorial marroquí, 1950.

ZiolkowsKi, Jan M (2010): Fairy Tales from Before Fairy Tales: The Medieval Latin Past of Wonderful Lies, Madison, University of Michigan Press.

Fecha de recepción: 5 de abril de 2019

Fecha de aceptación: 17 de mayo de 2019 